УДК 364:614.215]:616.9-036.21

DOI https://doi.org/10.32782/humanitas/2021.2.3

\title{
Мар'яна МАТВІЙЧУК
}

аспірантка кафедри соиіальної роботи та педагогіки вищої школи, Волинський національний університет імені Лесі Украӥнки, просп. Волі, 13, м. Луиьк, Волинська обл., Украйна, 43025

ORCID: 0000-0001-7310-3308

Бібліографічний опис статті: Матвійчук, М. (2021) Діяльність дитячих закладів оздоровлення та відпочинку в період поширення коронавірусної хвороби. Humanitas, 2, 19-23, doi: https://doi.org/10.32782/humanitas/2021.2.3

\section{ДІЯЛЬНІСТЬ ДИТЯЧИХ ЗАКЛАДІВ ОЗДОРОВЛЕННЯ ТА ВІДПОЧИНКУ В ПЕРІОД ПОШИРЕННЯ КОРОНАВІРУСНОЇ ХВОРОБИ}

У статті наведено перелік основних факторів захворюваності дітей, визначено, що саме ия категорія населення є не стійкою й не захищеною ланкою суспільства, яка потребує повноцінного відновлення в дитячих закладах оздоровлення та відпочинку. Відповідно до цьього представленні основні нормативно-праві документи країни, якими у своїй діяльності послуговуються дитячі заклади оздоровлення та відпочинку. Зазначено, щчо в період поширення коронавірусної хвороби перелік законодавчих документів, які регулюють їхню діяльність збільшується, а суспільству та установам доводиться працювати в нових жорстких умовах. Визначено основні видозмінені аспекти оздоровчої кампанії, шляхи впровадження чіткого механізму для створення сприятливих послуг для оздоровлення та відпочинку дітей.

Доводиться актуальність даного дослідження. На основі наукових розвідок педагогічної літератури окреслено основні завдання, компоненти готовності, мету діяльності й зміст роботи соціального працівника у закладах оздоровлення та відпочинку. Окреслені нами характеристики дають змогу зробити висновок про постійну динаміку, вдосконалення й розширення спектру діяльності працівника в сучасних умовах.

У статті здійснено аналіз нових вимоги до організаиї діяльності закладу та правила, що розповсюджуються на всіх учасників оздоровчо-відпочинкового прочесу. Запропоновано правила діяльності дитячого закладу оздоровлення та відпочинку на період карантину у зв'язку з поширенням коронавірусної хвороби що стосуються: перевезення, прийому й перебування дітей в закладі оздоровлення та відпочинку; проведення активного відпочинку в приміщенні, на вулиці, біля водойми; розміщення їх в кімнатах і загонах.

Зроблено висновок про чітку організаџію діяльності дитячих закладів оздоровлення та відпочинку в майбутньому із залученням сочіальних працівників як найбільш кваліфікованих спеціалістів. Дослідження теми дасть змогу зробити аналіз діяльності закладу в період карантину й поширення коронавірусноїхвороби, а також адаптації дітей до нових умов закладу оздоровлення та відпочинку в наступних дослідженнях.

Ключові слова: оздоровлення, відпочинок, дитячий заклад оздоровлення та відпочинку, сочіальний працівник, карантин, коронавірусна хвороба.

\section{Mariana MATVIICHUK}

Postgraduate Student at the Department of Social Pedagogy and Pedagogy of Higher School, Lesya Ukrainka Volyn National University, 13 Voli ave., Lutsk, Volyn region, Ukraine, 43025

ORCID: 0000-0001-7310-3308

To cite this article: Matviichuk, M. (2021) Diialnist dytiachykh zakladiv ozdorovlennia ta vidpochynku $\mathrm{v}$ period poshyrennia koronavirusnoi khvoroby [Functioning of children's healthcare and leisure institutions during coronavirus disease]. Humanitas, 2, 19-23, doi: https://doi.org/10.32782/humanitas/2021.2.3

\section{FUNCTIONING OF CHILDREN'S HEALTHCARE AND LEISURE INSTITUTIONS DURING CORONAVIRUS DISEASE}

The article lists the main factors of children's morbidity and determines that this category of the population is not a stable and unprotected part of society, which needs full recovery in children's healthcare and leisure institutions. Accordingly, the main legal documents of the country, which are used in their activities by children's healthcare and leisure institutions, are presented. It is noted that during the period of quarantine and coronavirus disease, the list of legislative documents governing their activities is increasing, and society and institutions have to work in new harsh conditions. The main modified aspects of the health campaign have been identified, as well as ways to implement a clear mechanism for creating favorable services for children's health and recreation. 
The relevance of this study is proved. Based on researches of the pedagogical literature the basic tasks, components of readiness, the purpose of the activity, and the maintenance of work of the social worker in establishments of improvement and rest are outlined. The characteristics outlined by us allow us to conclude the constant dynamics, improvement, and expansion of the range of activities of the employee in modern conditions.

The article analyzes the new requirements for the organization of the institution and the rules that apply to all participants in the health and recreation process. We have proposed the rules of operation of the children's health and recreation facility for the period of quarantine in connection with the spread of coronavirus disease concerning: transportation, reception, and stay of children in the healthcare and leisure institution; active recreation indoors and outdoors, as well as near the pond; placing them in rooms and pens.

It is concluded that the activities of children's health and recreation facilities in the future will be organized with the involvement of social workers as the most qualified specialists. The study of the topic will allow analyzing the activities of the institution during the quarantine and spread of coronavirus disease, as well as the adaptation of children to the new conditions of the institution of health and recreation in subsequent studies.

Key words: rehabilitation, rest, children's healthcare and leisure institutions, social worker, quarantine, coronavirus disease.

Сучасний стан епідеміологічної ситуації в країні, що спричинений коронавірусною хворобою зумовлює особливе ставлення до здоров'я дітей та підлітків. Тенденція щодо погіршення медичних показників молоді невпинно зростає. До екологічних, соціальноекономічних й психологічних факторів додався епідеміологічний, що в сучасних умовах розвитку суспільства диктує нові правила організації навчальних й виховних процесів. Не стала виключенням організація оздоровлення та відпочинку дітей в літній період. Діти, як найбільш не стійка, не захищена ланка суспільства потребують повноцінної стабільної уваги і продовження їх підконтрольної діяльності у відпочинкових та оздоровчих заходів. Кількість закладів, що надають такі послуги щороку зменшується, а попит зростає.

Діяльність дитячих закладів оздоровлення та відпочинку регулюють нормативно-правові документи держави: Конституція України, Закон України «Про оздоровлення та відпочинок дітей», Закон України «Основи законодавства України про охорону здоров'я», Закон України «Про соціальну роботу 3 дітьми й молоддю», Закони України «Про освіту», «Про позашкільну освіту», розпорядження Президента України та постанови Кабінету Міністрів, розпорядження органів місцевої виконавчої влади і рішень органів місцевого самоврядування. Важливим документом, який регламентує аспекти діяльності закладів оздоровлення та відпочинку є «Типове положення про дитячий оздоровчий заклад», де зазначено, що «оздоровчий табір є позашкільним оздоровчо-виховним закладом і створюється ... 3 метою організації змістовного дозвілля і відпочинку, зміцнення здоров'я, задоволення інтересів і духовних запитів дітей, підлітків і учнівської молоді» [2, с. 11].

Задля виконання вищезазначених послух, в умовах карантину у зв'язку 3 поширенням коронавірусної хвороби (COVID-19) перед початком літнього сезону працівники дитячих закладів оздоровлення та відпочинку ознайомлюються із актуальними законодавчими документами, які диктують нові правила прийому й перебування дітей, а також рекомендації щодо їх роботи.

Відповідно до статті 40 Закону України про затвердження санітарного та епідемічного благополуччя населення», на виконання пункту 2 постанови Кабінету Міністрів України від 20 травня 2020 року № 392 «Про встановлення карантину 3 метою запобігання поширенню на території України гострої респіраторної хвороби COVID-19, спричиненої коронавірусом SARS-CoV-2, та етапів послаблення протиепідемологічних заходів» Міністерством охорони здоров’я видано постанову № 43 від 30.07.2020 «Про затвердження Тимчасових рекомендацій щодо організації протиепідемічних заходів у дитячих закладах оздоровлення та відпочинку на період карантину у зв'язку з поширенням коронавірусної хвороби COVID-19». У постанові йдеться про те, що організація протиепідемічних заходів у дитячих закладах оздоровлення та відпочинку здійснюється відповідно до вимог Державних санітарних правил і норм «Улаштування, утримання і організація режиму діяльності дитячих оздоровчих закладів» ДСаПіН 5.5.5.23-99, затверджених постановою Головного державного санітарного лікаря України від 26.04.1999 №23, Державних санітарних правил розміщення, улаштування та експлуатації оздоровчих закладів, затверджених наказом 
МО3 України від 19.06.96 року №172 і з урахуванням цих тимчасових рекомендацій, спрямованих на запобігання ускладнення епідемічної ситуації внаслідок поширення коронавірусної хвороби (COVID-19) [3, с. 1].

Актуальність даного дослідження полягає в тому, що в період дії нових карантинних вимог для чіткого регулювання діяльності дитячого закладу оздоровлення та відпочинку ми повинні враховувати такі аспекти:

- зв'язок чинних нормативно-правових документів та запровадження нових;

- діяльність в закладі оздоровлення та відпочинку спеціалістів, які відповідають новим тенденціям сучасності та підлаштовуються під вимоги часу. Саме такими ми вважаємо є діяльність соціального працівника;

- нові запропоновані державою правила роботи дитячих закладів оздоровлення та відпочинку, та впровадження їх в діяльність безпосередньо учасниками процесу.

Спираючись на дослідження науковців ми можемо окреслити завдання соціального працівника: попередження проблем, виявлення й усунення своєчасних причин, що сприяють ïx виникненню, а також профілактика різноманітних негативних явищ (моральних, фізичних, соціальних) у дитячому закладі оздоровлення та відпочинку.

Слід наголосити, що готовність до діяльності в літніх оздоровчих таборах - це цілісна характеристика особистості. Ї̈ї структура грунтується на врахуванні таких компонентів:

1) особистісні якості (психологічні та професійно важливі);

2) професійна спрямованість (сукупність мотивів педагогічної діяльності; інтерес до неї, ціннісні орієнтації);

3) знання, необхідні для роботи в літніх оздоровчих таборах;

4) уміння як рівень майстерності у використанні набутих знань [5, с. 11].

Важливе у роботі соціального працівників в дитячих закладах оздоровлення та відпочинку становить позитивне ставлення до професії, усвідомлення мотивів, потреб і функцій, наявність професійно-важливих якостей особистості, іiі соціальної зрілості, почуття відповідальності за власну діяльність, а також відповідні знання, вміння і навички. Мета діяльності соціального працівника в дитячих закладах оздоровлення та відпочинку полягає у розширенні, поглибленні і закріпленні професійно-педагогічних знань, у набутті досвіду самостійної організації життя й діяльності тимчасового дитячого та підліткового колективів, в удосконаленні умінь і навичок роботи 3 дітьми та підлітками в умовах літніх канікул, у виявленні стійкого інтересу та поваги до професії, у виробленні творчого, дослідницького підходу, а також потреби у самопізнанні, самоосвіті і самовдосконаленні $[1$, с. 3$]$.

Змістом роботи соціального працівника в літніх таборах є:

- ознайомлення 3 умовами побуту, правилами внутрішнього розпорядку, традиціями оздоровчого закладу, планування роботи дитячого колективу, формування органів табірного самоврядування;

- вивчення специфіки проявів вікових, індивідуальних особливостей дітей, стану їхнього здоров'я, умов життя та виховання;

- організація самообслуговування, колективно-творчої діяльності за всіма напрямами виховання (розумового, морального, естетичного, трудового, фізичного, екологічного);

- забезпечення активного відпочинку дітей, дотримання режиму проведення санітарнооздоровчої й індивідуальної виховної роботи 3 ними [4, с. 12].

Окреслені нами характеристики діяльності соціального працівника дають змогу говорити про постійне вдосконалення та розширення спектру діяльності в сучасних умовах. В епоху цифрових технологій та діджиталізації суспільства роллю соціального працівника стало доведення до відома батьків та дітей основних правил, які діятимуть у дитячому закладі оздоровлення та відпочинку за нових умов.

Зазначимо, що з 1 серпня 2020 року робота дитячих закладів оздоровлення та відпочинку була дозволена лише із «зеленими» $\mathrm{i}$ «жовтими» рівнями епідемічної небезпеки, проте перевезення та перебування мало відповідати певним правилам. Враховуючи їх, а також наближення оздоровчо-літнього періоду, на основі всіх законодавчих документів ми пропонуємо правила діяльності дитячого закладу оздоровлення та відпочинку на період карантину у зв'язку з поширенням коронавірусної хвороби COVID-19.

Опрацювавши ряд нормативно-правових документів ми виділили правила перевезення 
дітей до закладу оздоровлення та відпочинку 3 якими соціальний працівник повинен ознайомити учасників процесу, а саме:

- перевезення дітей до закладу може здійснюватися організованими групами автомобільним чи залізничним транспортом. Допускається транспортування дитини батьками у власному авто;

- температурний скринінг працівників, дітей і супроводжуючих осіб під час перевезення;

- при перевезені необхідно забезпечити дистанцію між водієм і пасажирами не менше 1 м або наявність фізичних бар'єрів;

- водій транспортного засобу та супроводжуючі особи повинні знаходитися в масках;

- при перевезені залізничним транспортом забороняється наявність у вагоні сторонніх осіб;

- у проведенні вологого прибирання з дезінфекційними засобами перед кожним рейсом.

Відповідно до змісту діяльності соціального працівника в його обов'язки входить ознайомлення із внутрішнім розпорядком та допомога в організації прийому дітей в табір. Можемо виділити основні видозмінені правила під час прийому дітей в дитячий заклад оздоровлення та відпочинку, а саме:

- враховуючи поширення коронавірусної хвороби, доцільним вважаємо проведення анкетування батьків або осіб, які їх замінюють, при заповненні реєстраційних форм щодо наявності результатів тестів, перенесених захворювань, контактів 3 хворими, а також відвідування місць, в яких були виявлені люди, інфіковані COVID-19;

- рекомендовано організовувати прийом до закладу дітей, що проживають в межах регіону, де розташовано заклад;

- температурний скринінг дітей перед прийомом в заклад й під час перебування тричі на день;

- до закладу не допускаються діти 3 підвищеною температурою;

- робота працівників організовується вахтовим методом в межах однієї зміни;

- батьки і особи, які їх замінюють на територію дитячого закладу оздоровлення та відпочинку не допускаються.

Забезпечення активного відпочинку дітей $\epsilon$ ще одним компонентом в спектрі діяльності соціального працівника. За короткий проміжок часу працівники табору уміло поєднують активний відпочинок з розвитком інтелектуальних ігор, виховання особистісних якостей з розвитком самостійності, створюють реальні умови для збереження i зміцнення здоров'я дітей, формують здоровий спосіб життя та сприяють розвитку гармонійних стосунків 3 людьми, природою і собою. Проте, відповідно до нових правил роботи закладу оздоровлення та відпочинку повинні діяти обмеження, що забороняють:

- масові заходи в приміщенні та за участі запрошених осіб;

- використання м'яких іграшок.

Основна діяльність дітей проходить в загонах, де вони насолоджуються спілкуванням між однолітками, грають в ігри й проводять час відповідно до розпорядку дня. Рекомендується обмежити кількість дітей в загонах до 15 , виходячи 3 можливості забезпечити належні протиепідемічні умови перебування в корпуcax i контроль за їх виконанням. При проведенні заходів в загоні, а також в закладі оздоровлення та відпочинку в цілому необхідно враховувати дистанцію між дітьми, обмежити заняття й ігри, що передбачають безпосередній фізичний контакт. Надавати пріоритет відпочинково-оздоровчим заходам, що проводяться на відкритому повітрі. Необхідно обмежити інвентар, що потребує багаторазового використання, або забезпечити проведення його дезінфекцію щоразу після використання. При можливості використовувати одноразове спорядження й інший інвентар.

Під час вибору дитячого закладу оздоровлення та відпочинку батьки орієнтуються на його розміщення, пріоритет надається гірській, лісовій місцевості, а також наявність природної чи штучної водойми. Такий вибір є цілком виправданий, адже це дозволяє дітям більше часу знаходитися на свіжому повітрі, приймати сонячні ванни, плавати. Це, безперечно, має позитивний вплив на здоров'я й розвиток дитини. Проте, відповідно до нових карантинних обмежень при наявності у закладі пляжної зони необхідно домогтися заборони доступу до неї сторонніх осіб. Особливу уваги слід надавати проведенню ігор і вправ, які б доносили дітям важливість індивідуальних заходів профілактики й фізичного дистанціювання.

Варто зазначити, що при дотриманні карантинних норм розміщення в кімнатах корпусів 
здійснюється з розрахунку не менше 5 квадратних метрів на одну дитину із забезпечення дистанції між ліжками щонайменше в 1,5 метри.

Запропоновані нами правила діяльності закладу на основі рекомендацій Міністерства охорони здоров'я дадуть можливість чітко організувати діяльність дитячих закладів оздоров- лення та відпочинку й залучитися підтримкою соціальних працівників як найбільш кваліфікованих спеціалістів. У наступних дослідженнях ми зможемо зробити аналіз діяльності закладу в період карантину й поширення коронавірусної хвороби, а також адаптації дітей до нових умов закладу оздоровлення та відпочинку.

\section{ЛІТЕРАТУРА:}

1. Навчальні програми: педагогіка школи, історія педагогіки, методика виховної роботи, основи педагогічної майстерності, педагогічна практика / М.I. Сметанський, В.І. Шахов, В.М. Галузяк та ін. Вінниця : «КонтинентПрим», 2004. 116 с.

2. Типове положення про дитячий оздоровчий заклад. Завуч. 2006. № 12. С. 11.

3. Про встановлення карантину з метою запобігання поширенню на території України гострої респіраторної хвороби COVID-19, спричиненої коронавірусом SARS-CoV-2, та етапів послаблення протиепідемологічних заходів: постанова Кабінету Міністрів України від 20 травня 2020 року №392 Міністерство охорони здоров’я. URL: https://moz.gov.ua/uploads/ckeditor/.

4. Цуприк С.І. Підготовка студентів вищих педагогічних навчальних закладів до роботи в літніх оздоровчих таборах : автреф. дис. на здобуття ступеня канд. пед. наук : 13.00.04. Вінниця, 2011. 22 с.

5. Яковлева О.П. Формування комунікативних умінь майбутніх учителів у процесі виховної роботи в оздоровчих таборах : автореф. дис. на здобуття ступеня канд. пед. наук: 13.00.07. Київ, 2002. 23 с.

\section{REFERENCES:}

1. Smetanskyi, M.I., Shakhov, V.I., Haluziak, V.M. et al. (Eds.) (2004). Navchalni prohramy: pedahohika shkoly, istoriia pedahohiky, metodyka vykhovnoi roboty, osnovy pedahohichnoi maisternosti, pedahohichna praktyka [Curricula: school pedagogy, history of pedagogy, methods of educational work, basics of pedagogical skills, pedagogical practice]. Vinnytsia: «KontynentPrym» [in Ukrainian].

2. Typove polozhennia pro dytiachyi ozdorovchyi zaklad [A typical provision for a children's health facility] (2006). Zavuch-Head teacher, 12, 11. [in Ukrainian].

3. Pro vstanovlennia karantynu z metoiu zapobihannia poshyrenniu na terytorii Ukrainy hostroi respiratornoi khvoroby COVID-19, sprychynenoi koronavirusom SARS-CoV-2, ta etapiv poslablennia protyepidemolohichnykh zakhodiv: postanova Kabinetu Ministriv Ukrainy vid 20 travnia 2020 roku №392 3. [On the establishment of quarantine in order to prevent the spread of acute respiratory disease COVID-19 caused by coronavirus SARS-CoV-2 in Ukraine, and the stages of easing anti-epidemic measures: Resolution of the Cabinet of Ministers of Ukraine of May 20, 2020] Ministerstvo okhorony zdorovia Retrieved from https://moz.gov.ua/uploads/ckeditor/ [in Ukrainian].

4. Tsupryk, S.I. (2011). Pidhotovka studentiv vyshchykh pedahohichnykh navchalnykh zakladiv do roboty v litnikh ozdorovchykh taborakh [Preparation of students of higher pedagogical educational institutions for work in summer health camps]. Extended abstract of candidate's thesis. Vinnytsia [in Ukrainian].

5. Iakovleva, O.P. (2002). Formuvannia komunikatyvnykh umin maibutnikh uchyteliv u protsesi vykhovnoi roboty v ozdorovchykh taborakh [Formation of communicative skills of future teachers in the process of educational work in health camps]. Extended abstract of candidate's thesis. Kyiv [in Ukrainian]. 